\title{
Glucosylated aroma precursors and glucosidase(s) in vanilla bean (Vanilla planifolia G. Jackson)
}

Éric ODoux

Cirad, Département Flhor, UPR Qualité des aliments, TA 50 / PS4, Blvd. la Lironde, Montpellier Cedex 5 , F-34398 France eric.odoux@cirad.fr
${ }^{*}$ Correspondence and reprints

Received 23 September 2005 Accepted 23 November 2005

Fruits, 2006, vol. 61, p. 171-184 (C) 2006 Cirad/EDP Sciences All rights reserved DOI: $10.1051 /$ fruits:2006015 www.edpsciences.org

RESUMEN ESPAÑOL, p. 184

\section{Glucosylated aroma precursors and glucosidase(s) in vanilla bean (Vanilla planifolia G. Jackson).}

Abstract - Introduction. The heat treatments applied to vanilla beans (Vanilla planifolia G. Jackson) during processing have various objectives, which include encouraging the hydrolysis of the glucosylated precursors of the aroma components by one (or several) endogenous glucosidase(s). The glucosides of the vanilla bean. Fifteen glucosides have been identified in the green fruit, of which glucovanillin is the most abundant. It can reach concentrations of up to $15 \%$ of fruit dry matter about 30 weeks after pollination, and represents the main form of accumulation of vanillin. $\beta$-D-glucosidase(s) of the vanilla bean. A $\beta$-D-glucosidase from the vanilla bean was purified and characterised. However, several glucosidases may exist and have yet to be studied. The glucosidase activity seems to be very unstable during the heat treatments. This raises questions about the process of glucoside hydrolysis during vanilla curing. Compartmentation between the glucosidase activity and glucosides in the vanilla bean. After various debates, it now appears that glucovanillin and glucosidase activity largely occur in the bean's placental region. Their respective cellular localisation has yet to be determined. However, numerous elements support the hypothesis that enzymatic hydrolysis is regulated by a cellular compartmentation that differs between enzyme and substrate. Conclusion. A great deal of research work still needs to be conducted on the glucosides and glucosidase(s) of the vanilla bean. It would be particularly interesting to further our understanding of what occurs during the enzymatic hydrolysis of aroma precursors during curing.

Vanilla planifolia / processing / aroma / glucosides / $\beta$ glucosidase

Précurseurs d'arômes glucosylés et glucosidase(s) dans la " gousse " de Vanilla planifolia G. Jackson.

Résumé - Introduction. Les traitements thermiques appliqués aux " gousses " du vanillier (Vanilla planifolia G. Jackson) pendant la transformation ont différents objectifs, dont celui de favoriser l'hydrolyse des précurseurs glucosylés de composés d'arôme par une (ou plusieurs) glucosidase(s) endogène(s). Les glucosides de la " gousse " du vanillier. Une quinzaine de glucosides ont pu être identifiés dans le fruit vert, parmi lesquels la glucovanilline est le plus important quantitativement. Trente semaines après la pollinisation, sa concentration peut atteindre $15 \%$ de la matière sèche du fruit. Ce glucoside représente la principale forme d'accumulation de la vanilline. $\beta$-D-glucosidase(s) de la "gousse " du vanillier. Une $\beta$-D-glucosidase a été purifiée et caractérisée à partir de la " gousse " du vanillier, mais il est possible que plusieurs glucosidases existent qui resteraient à étudier. L'activité glucosidasique semble très instable au cours des traitements thermiques, ce qui pose des questions quant au processus d'hydrolyse des glucosides pendant la transformation de la vanille. Compartimentation entre activité glucosidasique et glucosides dans la " gousse " du vanillier. Après différentes controverses, il semble désormais acquis que la glucovanilline et l'activité glucosidasique sont majoritairement localisées dans la partie placentaire de la " gousse ". Leur localisation cellulaire respective reste à préciser, mais de nombreux éléments confortent l'hypothèse que l'hydrolyse enzymatique est régulée par une compartimentation cellulaire différente entre enzyme et substrat. Conclusion. De nombreux travaux de recherche restent à entreprendre sur les glucosides et glucosidase(s) de la " gousse " du vanillier et il serait notamment intéressant de mieux connaître le déroulement du processus d'hydrolyse enzymatique des précurseurs d'arômes pendant la transformation.

Vanilla planifolia / traitement / arôme / glucoside / $\beta$ glucosidase 


\section{Introduction}

The traditional method used to process the fruit of Vanilla planifolia (which professionals call curing) involves three main steps: heat-treating the green fruit, drying and, finally, a maturing phase.

The main reason for heat-treating Vanilla planifolia is to prevent fruit dehiscence ( $V$. tahitensis is not dehiscent and, therefore, is not subject to heat treatment), which gives an end product of inferior commercial quality. In fact, the fruit is harvested deliberately before the stage of maturity when dehiscence occurs. However, this premature harvesting is not sufficient to stop the process altogether. Therefore, different simple techniques have been developed that are compatible with curing on a village level in producer countries, i.e., with very limited technical means. The most common technique is that of "killing", which involves soaking in hot water (about $60^{\circ} \mathrm{C}$ ) for a few minutes (figure 1), followed by sweating in crates for $24-72 \mathrm{~h}$. Cold treatments have also been proposed [1, 2].

The second stage of the process involves drying the vanilla deliberately slowly. This is done by spreading the beans on trays in the sun and in the shade and heaping them in blankets under cover (figure 1). The operation can take 3-4 months.

The main objective of drying is obviously to stabilise the product in order to avoid the development of microorganisms, particularly mould. The water content of the beans decreases steadily from around $85 \%$ to maximum contents of $25-38 \%$, depending on the commercial categories. In practice, vanilla destined for the food-processing industry ( $80 \%$ of the market) is dried until it reaches $18-20 \%$ moisture content, which still corresponds to high water activities (Aw) of around $0.75-0.8$.

Lastly, the final stage involves maturing in a confined atmosphere for several months.

The dried beans are put in small bunches (usually after they have been sorted according to size and colour) and placed in a metal box or wooden crate, lined with waxed paper (figure 1) to reduce desiccation as far as possible. The boxes are opened regularly to check that there has been no mould development. The vanilla is considered ready for sale after it has been stored in this way for several months.

During these different treatments, numerous enzymatic and chemical reactions are triggered [3-14] and encouraged by the considerable water activity in the product and the high temperature to which it is regularly exposed. This causes considerable changes in colour (figure 1), texture and smell. From a strictly aromatic point of view, the successful development of the process means that a green fruit, with no interesting olfactory characteristics, develops into a product with perfectly developed aromas.

Many of the components of aroma, which produce the sought-after quality [15], are the result of a set of complex reactions (protein breakdown, lipid oxidation, the Maillard reaction, etc.). These reactions may, or may not, be catalysed by endogenous enzymatic systems - they may even be partly due to the proliferation of microorganisms [16] but little is known about the exact mechanisms involved.

However, when the fruit is harvested, it already contains glucosylated precursors therefore, with no olfactory properties which need to be hydrolysed by one (or several) endogenous glucosidase(s) in order to release the aromatic part of the molecule from the glucose.

Some research has been conducted on these glucosylated precursors and glucosidase(s).

\section{The glucosides in vanilla beans}

\subsection{The glucosylated components of vanilla}

For a long time, it was suspected that, at the normal harvest stage, the green fruit of vanilla contained aroma precursors in glucosyl form. After some debate [17-19], it was established that the "vanilloside" (the glucovanillin) was the direct precursor of vanillin and that there were also three other less 


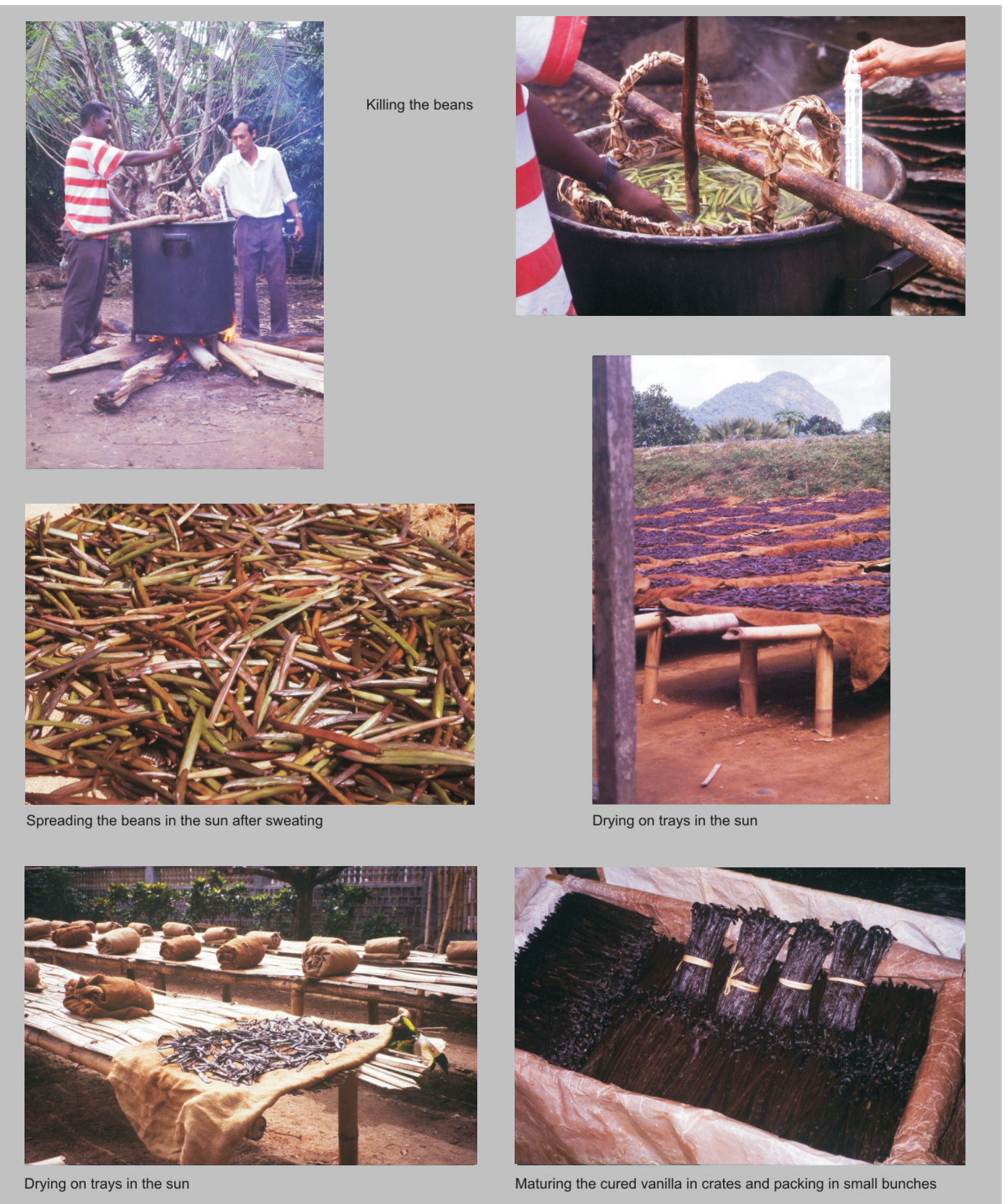

abundant precursors: glucosides from vanillic alcohol (vanilloloside), protocatechualdehyde (3,4-dihydroxybenzaldehyde), and an unidentified ester [20, 21] (figure 2).
More recently, glucosides of vanillin, Principal stages in traditional p-hydroxybenzaldehyde, $p$-hydroxybenzoic vanilla curing (Vanilla planifolia). acid and vanillic acid were identified in the (A color version is only available green bean ( $V$. planifolia originating from at www.edpsciences.org.) 


\section{É. Odoux}

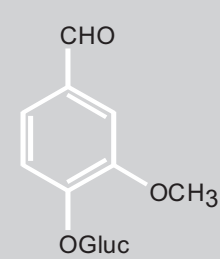

glucovanillin

(vanilloside)

$[20,24,26,27]$

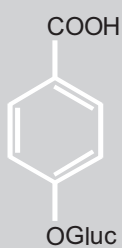

p-hydroxybenzoic acid glucoside

[24]

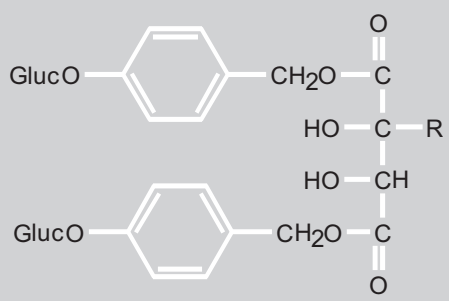

$\mathrm{R}=\quad \mathrm{CH}\left(\mathrm{CH}_{3}\right)_{2} \quad$ : glucoside $\mathrm{A}$

$\mathrm{R}=\mathrm{CH}\left(\mathrm{CH}_{2} \mathrm{CH}_{3}\right)\left(\mathrm{CH}_{3}\right):$ glucoside $\mathrm{B}$

$[26,27]$

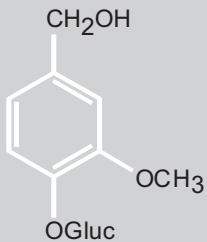

vanillic alcohol glucoside (vanilloloside)

[20]

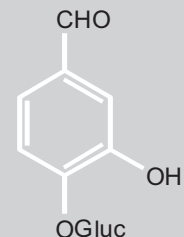

protocatechuic aldehyde glucoside

[20]

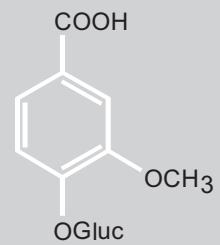

vanillic acid

glucoside

$[24,27]$

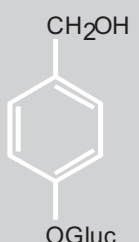

p-hydroxybenzyl alcoho glucoside $[26,27]$

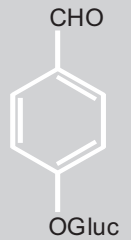

p-hydroxybenzaldehyde glucoside $[24,26,27]$

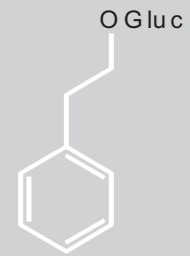

2-phenylethanol glucoside [26]

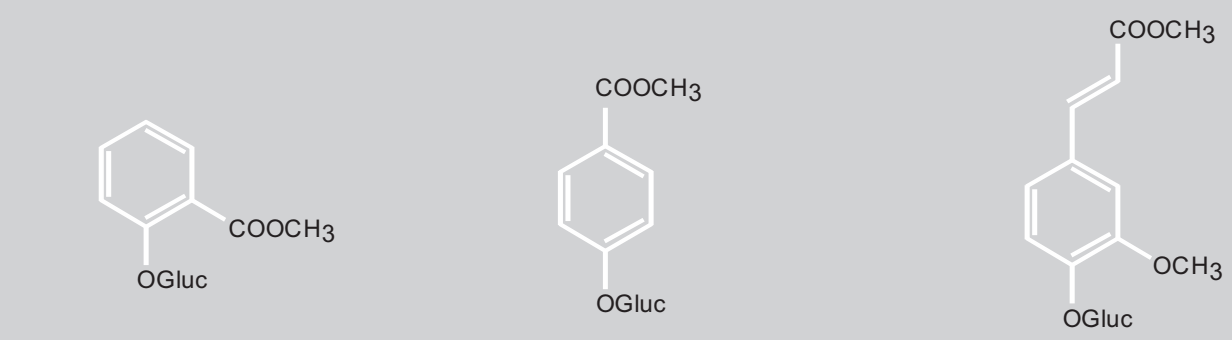

salicilic acid methyl ester glucoside

[26] p-hydroxybenzoic acid methyl ester
glucoside

p-hydroxybenzoic acid methyl ester
glucoside

[26]

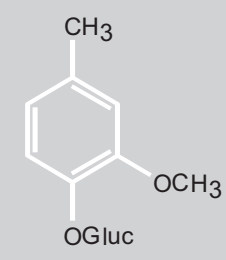

creosol glucoside [27]

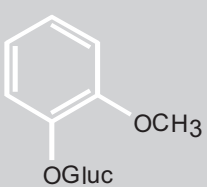

guaiacol glucoside [12] resol glucoside

$$
[26,27]
$$

ferulic acid methyl ester glucoside

\section{Figure 2.}

Chemical structures of the different glucosides identified in the green beans (Vanilla planifolia) according to the authors. 
the Comoro Islands, Reunion, Madagascar and Indonesia), with the help of modern analytical techniques [22-24] (figure 2).

According to Kanisawa et al. [25], the four main glucosides in the green bean ( $V$. planifolia originating from Indonesia) are glucovanillin, $p$-hydroxybenzyl- $\beta$-D-glucopyranoside, bis[4-( $\beta$-D-glucopyranosyloxy)benzyl] 2-isopropyl tartrate (glucoside A) and bis[4-( $\beta$-D-glucopyranosyloxy)-benzyl] 2-(1-methyl-propyl) tartrate (glucoside B). The $p$-hydroxybenzyl- $\beta$-D-glucopyranoside and the glucosides A and B seem to be intermediates in the phenolic compounds' biosynthetic pathway.

Kanisawa [26] was also able to identify the glucosides of $p$-hydroxybenzaldehyde, $p$-cresol, 2-phenylethanol, ferulic acid methyl ester, salicylic acid methyl ester and $p$ hydroxybenzoic acid methyl ester (figure 2).

In a study that was published recently, Dignum et al. [27] conducted research on the presence of different glucosides in the green bean ( $V$. planifolia originating from Indonesia). The different glucosides identified are vanillin, vanillic acid, $p$-hydroxybenzaldehyde, $p$-cresol, creosol and $p$-hydroxybenzylalcohol, as well as glucosides A and B. In a previous study [12], these authors also found the glucoside of guaiacol, that they did not find subsequently (figure 2).

\subsection{Evolution of glucosides during bean development}

Research has only been published on the evolution of vanillin and glucovanillin during the fruit's development on the vine [8, $25,28-30]$.

The only point of agreement that has emerged from the different research is that the accumulation of vanillin or glucovanillin in the fruit starts after the 15th week following pollination and continues until around the 30th week.

However, the form in which vanillin is accumulated (free or glucosyl form) can lead to confusion. Ranadive et al. [8] and Sagrero-Nieves and Schwartz [28] show the evolution of free vanillin without prior hydrolysis, which, according to the first author, would represent between 50\% and $90 \%$ of the potential total of vanillin.

Brodélius [29] considers that most of the vanillin is in glucosyl form with the free form not exceeding $15 \%$ of the potential total. Kanisawa et al. [25] do not report the presence of vanillin in its free form during the development of the green fruit and HavkinFrenkel et al. [30] indicate that vanillin is only accumulated in its glucosyl form. The last point is confirmed by Leong [24] who does not find the free form in the green beans. Arana [31] has already found that vanillin is present almost exclusively in the glucosyl form.

Similarly, the contents obtained in green fruit after 8 months of development differ completely from one author to another. The different values obtained compared with dry matter and vanillin potential range from between 1\% [28] and $6 \%$ of vanillin [30] Other types of research have confirmed that the green beans could contain from 5\% to $7 \%$ dry matter of vanillin in glucosyl form $[2,14,24,32,33]$.

\subsection{The biosynthetic pathway of glucosides in the bean}

For a while, it was thought that coniferyl alcohol and its glucoside were involved in the biosynthesis of vanillin [17-19]. However, this hypothesis was abandoned fairly rapidly [20]. Now, it is agreed that vanillin is a product of the biosynthetic pathway of shikimic acid, via phenylalanine, which leads to phenylpropane compounds through enzymatic deamination, and primarily cinnamic acid (figure 3). Successive enzymatic hydroxylations and methylations then lead to the formation of $p$-hydroxycinnamic acids and, notably, coumaric, caffeic, ferulic and sinapic acids.

Different research on the fruit [25, 26, 34] and cell culture [35-42] has been conducted on the following stages, although it has not been possible to establish an indisputable biosynthetic pathway. However, the research has shown that the biosynthetic pathways of vanillin can be different, depending 


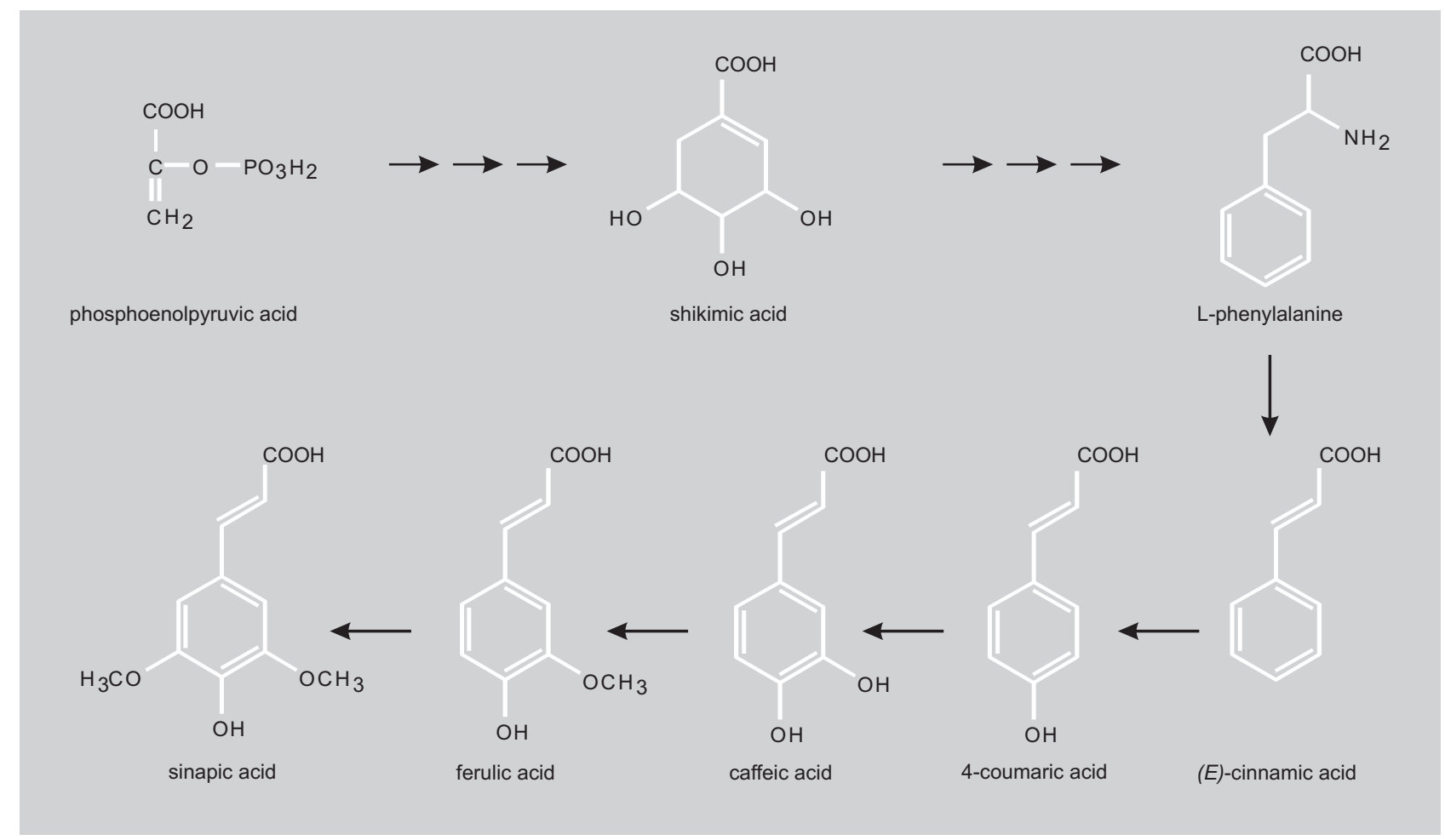

\section{Figure 3.}

Presumed biosynthetic pathway of the phenylpropane compounds from shikimic acid and phenylalanine. on whether the plant or cell culture is concerned.

In Vanilla planifolia plants, Kanisawa [26] proposed, from the different glucosides he identified in the green pod, the glucosylation of 4-coumaric acid and then its conversion to glucoside of $p$-hydroxybenzaldehyde. From this last compound, he proposed two possible pathways for glucovanillin biosynthesis; a first one via the formation of glucoside of protocatechuic aldehyde, and a second one via the formation of glucoside of $p$-hydroxybenzylalcohol and glucosides $\mathrm{A}$ and $\mathrm{B}$ (figure 4 ).

Other works [30, 43, 44] confirm the rule of $p$-hydroxybenzaldehyde and protocatechuic aldehyde in vanillin biosynthesis, via an unstable 4-hydroxyphenyl- $\beta$-hydroxypropionic acid intermediate, but on their aglycon forms (figure 5). This pathway is supported by purification of a 4-hydroxybenzaldehyde synthetase (4HBS) and a methyltransferase (DOMT), that can catalyse, respectively, conversion of 4-coumaric acid to 4-hydroxybenzaldehyde and 3,4-dihydroxybenzaldehyde (protocatechuic aldehyde) to vanillin.

\section{3. $\beta$-D-glucosidase(s) of the vanilla bean}

\subsection{Proof of the existence and characterisation of a $\beta$-glucosidase in the bean}

The idea that one (or several) enzymatic systems are involved in the development of the vanilla aroma was first put forward by Miller in 1754 (quoted by Janot [21]). Lecomte [17] was then able to prove the existence of ferments hydratant et oxydant - probably the origin of the term fermentation which is still often incorrectly associated with vanilla curing - and studied their role in the development of the vanilla aroma.

After glucovanillin (and other glucosides) had been isolated and the glucosidase activity in the raw extracts of the green bean had been measured, it seemed clear that the main reaction involved in the aromatic development of vanilla was the hydrolysis of the glucosylated compounds by a glucosidase, the ferment bydratant [31]. However, as far as we know, until recently, the 


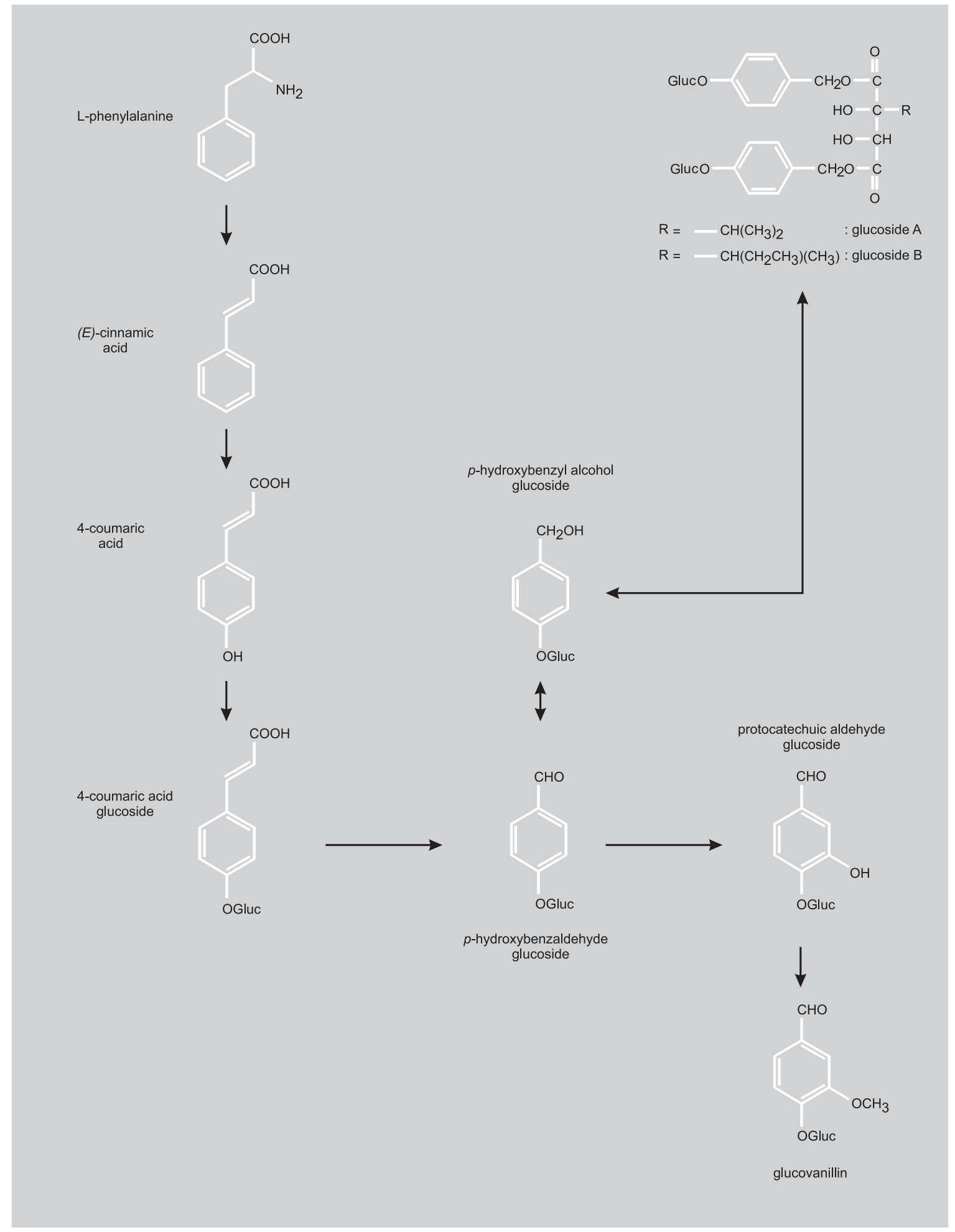

Figure 4.

Biosynthetic pathway of glucovanillin proposed by Kanisawa [26]. 


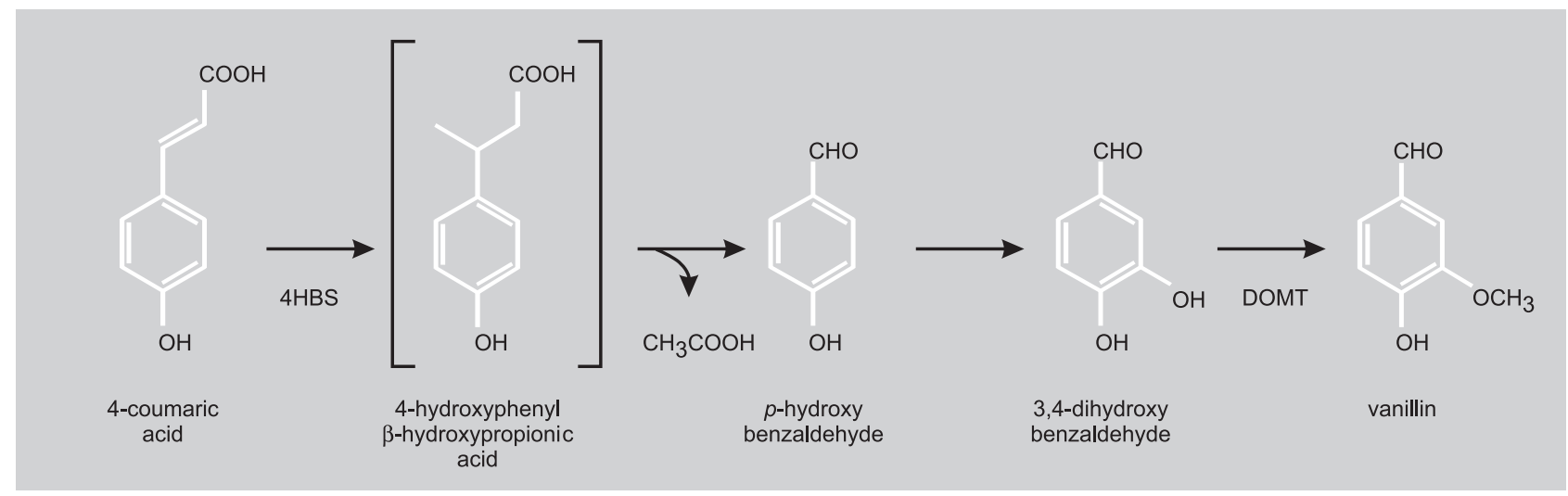

\section{Figure 5.}

Biosynthetic pathway of vanillin from 4-coumaric acid as proposed by Havkin-Frenkel et al. [30], Podstolski et al. [43] and Pak et al. [44] (4HBS = 4hydroxybenzaldehyde synthetase; DOMT = 3,4dihydroxybenzaldehyde-Omethyltransferase). existing bibliography made no mention of research on the purification and characterisation of a vanilla glucosidase.

Kanisawa et al. [25] mentioned the existence of two $\beta$-glucosidases in green vanilla beans: one is very specific to glucovanillin and $p$-hydroxybenzaldehyde glucoside, and the other has a much broader spectrum of activity. These results were obtained after precipitation using ammonium sulfate and cation exchange chromatography. However, the experimental results are not included in the publication.

Only research conducted by Odoux et al. [45] takes account of the purification and characterisation of a $\beta$-glucosidase of vanilla. An enzyme was isolated, with a native molecular weight of $200 \mathrm{kDa}$, an optimal $\mathrm{pH}$ of 6.5 , an optimal temperature of $40^{\circ} \mathrm{C}$, a $K m$ of $1.1 \mathrm{mM}$ with $p$-nitrophenyl $\beta$-D-glu-

Table I.

Kinetic parameters of the unpurified enzyme of green beans (Vanilla planifolia) with different glucosides used as a substrate (from Dignum et al. [27]).

\begin{tabular}{lcc} 
Glucosides of: & $\begin{array}{c}\text { Vm } \\
\left(\mathrm{Ul} \cdot \mathrm{mg}^{-1} \text { proteins }\right)\end{array}$ & $\begin{array}{c}\mathrm{Km} \\
(\mathrm{mM})\end{array}$ \\
\hline Vanillin & 9.4 & 5.1 \\
Ferulic acid & 4.9 & 5.3 \\
Vanillic acid & 3.1 & 21.3 \\
p-hydroxybenzaldehyde & 10.6 & 6.9 \\
Cresol & No hydrolysis & - \\
Creosol & 6.7 & 29.4 \\
Guaiacol & 15.9 & 131.8 \\
2-phenylethanol & No hydrolysis & -
\end{tabular}

copyranoside ( $p$ NPG) and $20 \mathrm{mM}$ with glucovanillin, and a $V_{m}$ of around $5 \mu \mathrm{katal} \cdot \mathrm{mg}^{-1}$ with the two substrates. Given the substrate used by these authors during the purification, it is not possible to draw any conclusions about the uniqueness of the $\beta$-glucosidase and, therefore, Kanisawa's hypothesis.

Hanum [9] obtains a $\mathrm{Km}$ value of $0.38 \mathrm{mM}$ with pNPG and Dignum et al. [27] obtain a $\mathrm{Km}$ value of $3.3 \mathrm{mM}$ from a raw enzyme extract of green beans. The latter also studied the kinetic parameters of the raw enzyme extract with different glucosides (table I).

\subsection{Evolution of the glucosidase activity during bean development}

According to the different authors who have monitored this evolution during bean development on the vine $[8,25,46]$, it would appear that the glucosidase activity is quantifiable at all stages of fruit growth. However, the enzyme activity does increase considerably between the third and the fourth month after pollination to a maximum at around the fifth month. Therefore, the evolution of the $\beta$-glucosidase activity during bean growth is in phase with that of glucovanillin.

\subsection{Effect of processing on glucosidase activity}

It is important to note that freezing the beans reduces glucosidase activity considerably [11, 45, 47], even though freezing constitutes the basis of two patents for vanilla curing 


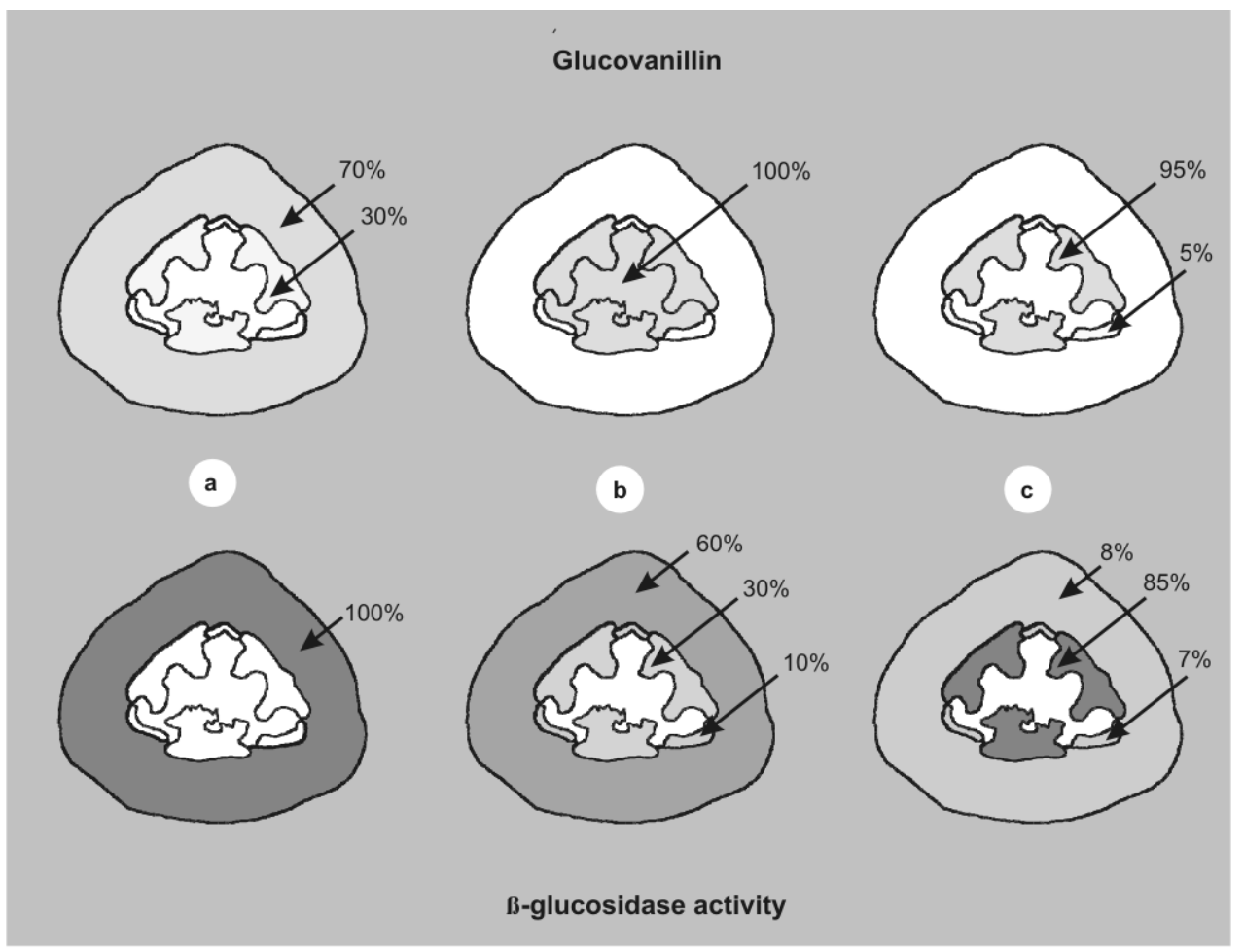

Figure 6.

Tissue localisation of glucovanillin and $\beta$-glucosidase activity according to Arana [31] and Jones and Vicente [5] (a), Joel et al. [49] and HavkinFrenkel et al. [14] (b) and Odoux et al. [51] (c).

and leads to levels of glucovanillin hydrolysis of over $80 \%$ in several hours [1, 2].

Several authors $[8,9,12,14,48]$ have monitored the glucosidase activity during the main steps of traditional curing or laboratory simulation.

Hanum [9] was the only author to find an increase in enzymatic activity (which is maintained for several days) after "killing". The other authors report total (or nearly total) losses in glucosidase activity in the first $24 \mathrm{~h}$ after heat treatment, even though the enzymatic hydrolysis of glucosides continues during the later stages. These authors agree on the fact that glucoside hydrolysis can only be of enzymatic origin.

Dignum et al. [12], like Kanisawa, conclude that there are two enzymes. The enzyme specific to glucovanillin (which is not detected with the pNPG test used) is not inactivated by the heat treatments.

Odoux [48] considers that an unmeasurable residual activity could occur, which would continue to hydrolyse glucosides with extremely slow kinetics.
Havkin-Frenkel et al. [14] consider that the extraction techniques and the dosage of enzymatic activity should be studied carefully because the proteases, phenols and products of oxidation present in the extracts could explain the low levels of activity measured.

\section{Compartmentation between the glucosidase activity and glucosides in the vanilla bean}

Very little research has been conducted to try to identify which parts of the fruit contain the glucoside precursors of the aroma components and the glucosidase activity.

However, for a long time De Lanessan [49] has implicitly suggested the hypothesis that the aroma precursors and the glucosidase activity occur in the central placental region, because he observed that only this part of the fruit had a characteristic smell after the bean had been cut in fine longitudinal slices from the external part towards the internal part. 
However, Arana [31] and Jones and Vicente [5] found that most glucovanillin (60-80\%) was found in the fleshy part of the bean (external mesocarp), and the rest was found in the internal placenta, whereas the enzymatic activity occurs exclusively in the external part of the bean [31] (figure 6a). Arana concludes that the glucovanillin in the internal part of the fruit has to spread to the external part where the enzyme is found (or the other way round), in order to be hydrolysed during vanilla curing or when the fruit matures on the vine. This hypothesis has been maintained by all the authors who have published work on vanilla during the last 60 years.

Recent research $[14,50]$ shows that glucovanillin (as well as the glucoside of $p$-hydroxybenzaldehyde) is found exclusively in the internal part of the fruit, not in the fleshy part, and that it could even be synthesised in the papillae and excreted by the latter into the extra-cellular space around the seeds. This would confirm Swamy's hypothesis [51]. However, Havkin-Frenkel et al. [14] found a decreasing gradient of enzymatic activity (expressed in terms of specific activity), from the external part towards the internal placental region as follows: $63 \%$ in the external region, $27 \%$ in the placental region and the rest in the papillae (figure 6b). Havkin-Frenkel et al. [14], whose results are diametrically opposed to those of Arana [31], also conclude that one or other compound must spread for the complete hydrolysis of the glucovanillin.

Odoux et al. [52] also showed that glucovanillin was only found in the internal part of the fruit and that it is mainly present in the placentas and, to a lesser extent, in the papillae. The fleshy part of the fruit is not involved at all. However, these authors $[48,52]$ found that more than $90 \%$ of the glucosidase activity (expressed in terms of total activity per mass unit of fresh tissue) occurs in the central region ( $85 \%$ in the placentas and $8 \%$ in the papillae, respectively), and the remainder (less than 10\%) in the fleshy part (figure 6c). In other words, there is a perfect superposition between the distribution of glucovanillin and the enzymatic activity. As a result, the components do not need to spread in the fruit tissue in order for hydrolysis to occur.

It is important to note that the results obtained by Havkin-Frenkel et al. [14] and Odoux et al. [52], that concern tissue localisation of glucosidase activity, are not necessarily contradictory. Indeed, the specific activity (the term Havkin-Frenkel et al. use to express glucosidase activity) is the ratio between the total activity and the protein content, and protein content seems to be much higher in the central part of the fruit than in the fleshy region. In a study of this type, the use of specific activity as a way of describing enzymatic activity is not justified and can lead to erroneous interpretations.

Although all these results may be contradictory, it is true that the different authors found that the enzyme and substrate do coexist in the same tissues - at least partially - and at the same stage of fruit development without triggering glucovanillin hydrolysis [8, 14, 26, 29-31, 46, 49], except at a very advanced stage of maturity when the beans turn black.

Odoux et al. [52] tried to understand how $\beta$-glucosidases regulate glucovanillin hydrolysis and, particularly, whether cellular compartmentation could explain it. At cellular level, the glucosidase activity is located in the cytoplasm or the apoplast. However, it is neither vacuolar nor parietal. Glucovanillin was not definitely located, but different considerations (high concentration and volume ratios of cellular compartments) suggest that it may be located in the vacuole, which is the preferred compartment for storing secondary metabolites [53-56]. It could also be located in the extra-cellular region around the seeds, as suggested by Swamy [51] and Joel et al. [50].

Using light microscopy, Odoux [48] was also able to show that, when the beans turn black after the natural maturing process or after the green beans have been defrosted, the cellular structures have been extremely damaged. This coincides with a complete hydrolysis of glucovanillin, which confirms the hypothesis of different cellular compartmentation between the enzyme and the substrate. The results obtained from the microscopic observations of the beans during the 
first stages of the process seem to indicate that heat treatment only has a partial effect on cellular integrity. This could explain the partial hydrolysis of vanillin during the first stages.

\section{Conclusion}

Fifteen aroma components in glucosyl form have been identified in the green fruit. Additional research should be undertaken to determine whether certain glucosides are present, which not everyone agrees with, and to try to identify if new ones exist.

The accumulation of these aroma components in the fruit during its development is still not very well understood. Only vanillin accumulation has been studied, although there is still considerable confusion about whether or not it is accumulated in glucosyl form. In fact, it appears that the glucosyl form is largely predominant in the green fruit, even if that does not exclude the presence of a fraction in free form. It would also be worth conducting much more complete studies on these different aspects (on several sites of production, etc.); in particular, the evolution of the ratio between the free and glucosyl forms during the development of the fruit, which could provide information on the physiological role of these components.

As far as the biosynthesis of these components is concerned, glucovanillin is the only one to have been studied. Different $p$-hydroxycinnamic acids are likely to be the precursors and, notably, ferulic and $p$-coumaric acids.

As far as $\beta$-D-glucosidases are concerned, at least one form has been purified. However, other $\beta$-D-glucosidases may exist, particularly because this enzymatic family is extremely multigenic. If other forms do exist, it would be interesting to try to purify them and compare their catalytic efficiency with regard to glucovanillin and other glucosides found in the vanilla bean.

It also appears that this or these glucosidases are responsible for the hydrolysis of glucosides during vanilla curing.
Despite considerable controversy and contradictory results, we think that glucosidase activity and glucovanillin (and probably the other glucosides) are mainly located in the placentas. Only a small amount of the glucosidase activity occurs in the mesocarp. It remains to be seen whether glucovanillin is also extra-cellular, which different observations seem to suggest, and in what form (free, associated with proteins, lipidic vesicles, etc.)

Lastly, different results seem to indicate that the limiting factor in glucoside hydrolysis is more linked to the cellular compartmentation than to the enzyme activity level; in other words, glucoside hydrolysis is complete if the treatment allows a total decompartmentation and if a sufficient residual glucosidase activity can continue. It would be worth clarifying exactly how the process develops.

\section{References}

[1] Balls A.K., Kevorkian A.G., Arana F.E., Process for curing vanilla beans, United States Patent Office, No. 2274120, USA, 1942, 1 p.

[2] Ansaldi G., Gil G., Le Petit J., Procédé d'obtention d'arôme naturel de vanille par traitement des gousses de vanille verte et arôme obtenu, Brevet, INPI, No. 2634979, France, 1988, 7 p.

[3] Rabak F., The effect of curing on the aromatic constituents of vanilla beans, J. Ind. Eng. Chem. 8 (1916) 815-821.

[4] Balls A.K., Arana F.E., The curing of vanilla, J. Ind. Eng. Chem. 33 (1941) 1073-1075.

[5] Jones M.A., Vicente G.C., Criteria for testing vanilla in relation to killing and curing methods, J. Agric. Res. 78 (1949) 425-434.

[6] Jones M.A., Vicente G.C., Inactivation and vacuum infiltration of vanilla enzyme systems, J. Agric. Res. 78 (1949) 435-444.

[7] Broderick J.J., A preliminary investigation of the quick curing of vanilla beans, Food Technol. 10 (1956) 188-189.

[8] Ranadive A.S., Szkutnica K., Guerrera J.G., Frenkel C., Vanillin biosynthesis in vanilla beans, in: Proc. 9th Int. Congr. Essent. Oils, Singapore, Malaysia, 1983, pp. 147-154. 
[9] Hanum T., Changes in vanillin and activity of $\beta$-glucosidase and oxidases during post harvest processing of vanilla bean (Vanilla planifolia), Bull. Teknol. Ind. Pengan VIII (1997) 46-52.

[10] Jiang M., Pu F., Xie W.-S., Hu Y.Q., Li Y., Activity of three enzymes in Vanilla capsule, Acta Bot. Yunnanica 22 (2000) 187-190.

[11] Dignum M.J.W., Kerler J., Verpoorte R., $\beta$-glucosidase and peroxydase stability in crude enzyme extracts from green beans of Vanilla planifolia Andrews, Phytochem. Anal. 12 (2001) 174-179.

[12] Dignum M.J.W., Kerler J., Verpoorte R., Vanilla curing under laboratory conditions, Food Chem. 79 (2002) 165-171.

[13] Dignum M., Biochemistry of the processing of vanilla beans, Univ. Leiden, Thesis, Leiden, Nederland, 2002, 103 p.

[14] Havkin-Frenkel D., French J.C., Pak F., Frenkel C., Inside vanilla: Vanilla planifolia's botany, curing options and future market prospects, Perfum. Flavor. 30 (2005) 36-55.

[15] Pérez-Silva A., Odoux E., Brat P., Ribeyre F., Rodriguez-Jimenes G., Robles-Olvera V., García-Alvarado M. A., Günata Z., GC-MS and GC-olfactometry analysis of aroma compounds in a representative organic aroma extract from cured vanilla (Vanilla planifolia G. Jackson) beans, Food Chem. (2006) 99 (4) 728-735.

[16] Röling W.F.M., Kerler J., Braster M., Apriyantono A., Stam H., Van Verseveld H.W., Microorganisms with a taste for vanilla: microbial ecology of traditional Indonesian vanilla curing, Appl. Environ. Microbiol. 67 (2001) 1995-2003.

[17] Lecomte H., Sur la formation du parfum de la vanille, CR Séances Acad. Sci. (Paris) T133 (1901) 745-748.

[18] Lecomte H., Formation de la vanilline dans la vanille, Agric. Prat. Pays Chauds 13 (1913) 3-14.

[19] Goris A., Sur la composition chimique des fruits verts de vanille et le mode de formation du parfum de la vanille, CR Acad. Sci. 179 (1924) 70-72.

[20] Goris A., Formation du parfum de la vanille, Ind. Parfum. 2 (1947) 4-12.

[21] Janot M.M., Formation du parfum de la vanille, in: Bouriquet G. (Eds.), Le vanillier et la vanille dans le monde, Paul Lechevalier, Paris, France, 1954.
[22] Leong G., Archavlis A., Derbesy M., Research on the glucosides fraction of the vanilla bean, J. Essent. Oil Res. 1 (1989) 33-41.

[23] Leong G., Uzio R., Derbesy M., Synthesis, identification and determination of glucosides present in green vanilla beans (Vanilla fragrans Andrews), Flavour Fragranc. J. 4 (1989) 163-167.

[24] Leong G., Contribution à l'étude des hétérosides des gousses de vanille vertes, Univ. Marseille III, Thèse, Marseille, France, 1991, $153 \mathrm{p}$.

[25] Kanisawa T., Tokoro K., Kawahara S., Flavour development in the beans of Vanilla planifolia, in: Kurihara K., Suzuki N., Ogawa H. (Eds.), Proc. Int. Symp., Tokyo, Japan, 1994, pp. 268-270.

[26] Kanisawa T., Flavor development in vanilla beans, Kouryou 180 (1993) 113-123.

[27] Dignum M.J.W., Van Der Heijden R., Kerler J., Winkel C., Verpoorte R., Identification of glucosides in green beans of Vanilla planifolia Andrews and kinetics of vanilla $\beta$-glucosidase, Food Chem. 85 (2004) 199-205.

[28] Sagrero-Nieves L., Schwartz S.J., Phenolic content of Vanilla planifolia as affected by harvest period, J. Food Compos. Analys. 1 (1988) 362-365.

[29] Brodelius P.E., Phenylpropanoid metabolism in suspension cultures of Vanilla planifolia Andr. V. High performance liquid chromatographic analysis of phenolic glycosides and aglycones in developing fruits, Phytochem. Anal. 5 (1994) 27-31.

[30] Havkin-Frenkel D., Podstolki A., Witkowska E., Molecki P., Mikolajczyk P., Vanillin biosynthetic pathways: an overview, in: Fu T.J., Singh G., Curtis W.R. (Eds.), Plant cell and tissue culture for the production of food ingredients, Kluwer Acad./Plenum Publ., New York, USA, 1999.

[31] Arana F.E., Action of a $\beta$-glucosidase in the curing of vanilla, Food Res. 8 (1943) 343351.

[32] Brunerie P.M., Procédé d'obtention d'arôme naturel de vanille par traitement enzymatique des gousses de vanille verte et arôme obtenu, Int. Pat. Appl., No. PCT/FR92/ 00837, France, 1993, 11 p.

[33] Odoux E., Changes in vanillin and glucovanillin concentrations during the various stages of the process traditionally used for 
curing Vanilla fragrans beans in Réunion, Fruits 55 (2000) 119-125.

[34] Zenk M.H., Biosynthese of vanillin in Vanilla planifolia Andr., Z. Pflanzenphysiol. 53 (1965) 404-414.

[35] Funk C., Brodelius P.E., Influence of growth regulators and an elicitor on phenylpropanoid metabolism in suspension cultures of Vanilla planifolia, Phytochem. 29 (1990) 845848.

[36] Funk C., Brodelius P.E., Phenylpropanoid metabolism in suspension cultures of Vanilla planifolia Andr. II. Effects of precursor feeding and metabolic inhibitors, Plant Physiol. 94 (1990) 95-101.

[37] Funk C., Brodelius P.E., Phenylpropanoid metabolism in suspension cultures of Vanilla planifolia Andr. III. Conversion of 4-methoxycinnamic acids into 4-hydroxybenzoic acids, Plant Physiol. 94 (1990) 102-108.

[38] Funk C., Brodelius P.E., Phenylpropanoid metabolism in suspension cultures of Vanilla planifolia Andr. IV. Induction of vanillic acid formation, Plant Physiol. 99 (1992) 256-262.

[39] Funk C., Brodelius P.E., Vanilla planifolia Andrews: in vitro biosynthesis of vanillin and other phenylpropanoid derivatives, in: Baja Y.P.S. (Ed.), Biotechnology in agriculture and forestry, Springer Verlag, Berlin-Heidelberg, Germany, 1994.

[40] Knorr D., Caster C., Dörneburg H., Dorn R., Gräf S., Havkin-Frenkel D., Podstolski A. Werrman U., Biosynthesis and yield improvement of food ingredients from plant cell and tissue cultures, Food Technol. (1993) 57-63.

[41] Havkin-Frenkel D., Podstolski A., Knorr D., Effect of light on vanillin precursors formation by in vitro cultures of Vanilla planifolia, Plant Cell Tiss. Org. 45 (1996) 133-136.

[42] Havkin-Frenkel D., Dorn R., Leustek T., Plant tissue culture for production of secondary metabolites, Food Technol. 51 (1997) 56-61.

[43] Podstolski A., Havkin-Frenkel D., Malinowski J., Blount J., Kourteva G., Dixon R.A., Unusual 4-hydroxybenzaldehyde synthase activity from tissue cultures of the vanilla orchid Vanilla planifolia, Phytochem. 61 (2002) 611-620.

[44] Pak F.E., Gropper S., Dai W.D., Havkin-Frenkel D., Belanger F.C., Characterization of a multifunctional methyltranferase from the orchid Vanilla planifolia, Plant Cell Rep. 22 (2004) 969-966.
[45] Odoux E., Chauwin A., Brillouet J.M., Purification and characterization of vanilla bean (Vanilla planifolia Andrews) $\beta$-D-glucosidase, J. Agric. Food Chem. 51 (2003) 3168-3173.

[46] Wild-Altamirano C., Enzymatic activity during growth of vanilla fruit. 1. Proteinase, glucosidase, peroxidase and polyphenoloxidase, J. Food Sci. 34 (1969) 235-238.

[47] Heckel E., De l'action du froid et des anesthésiques sur les feuilles de Angaecum fragrans Thou. (Faham) et sur les gousses vertes de la vanille, C.R. Acad. Sci. (Paris) 151 (1910) 128-131.

[48] Odoux E., Contribution à l'étude de I'hydrolyse de la glucovanilline en vanilline dans la «gousse » du vanillier (Vanilla planifolia G. Jackson), Univ. Montpellier II, Thèse, Montpellier, France, 2004, 149 p.

[49] De Lanessan J.-L., Vanille, in: de Lanessan J.-L. (Eds.), Les plantes utiles des colonies françaises, Impr. Natl., Paris, France, 1886.

[50] Joel D.M., French J.C., Graft N., Kourteva G., Dixon R.A., Havkin-Frenkel D., A hairy tissue produces vanillin, Isr. J. Plant Sci. 51 (2003) 157-159.

[51] Swamy B.G.L., On the life-history of Vanilla planifolia, Bot. Gaz. 108 (1947) 449-456.

[52] Odoux E., Escoute J., Verdeil J.L., Brillouet J.-M., Localization of $\beta$-D-glucosidase activity and glucovanillin in vanilla bean (Vanilla planifolia Andrews), Ann. Bot. 92 (2003) $437-$ 444.

[53] Boudet A.M., Alibert A., Marigo G., Vacuoles and tonoplast in the regulation of cellular metabolism, in: Membranes and compartmentation in the regulation of plant functions, Clarendon Press, Oxford, UK, 1984.

[54] Wink M., Compartmentation of secondary metabolites and xenobiotics in plant vacuoles, Adv. Bot. Res. 25 (1997) 141-169.

[55] Beckman C. H., Phenolic-storing cells: keys to programmed cell death and periderm formation in wilt disease resistance and in general defence responses in plants? Physiol. Mol. Plant Pathol. 57 (2000) 101-110.

[56] Bartholomew D.M., Van Dyk D.E., Cindy Lau S.-M., O'keefe D.P., Rea P.A., Viitanen P.V., Alternate energy-dependent pathways for the vacuolar uptake of glucose and glutathione conjugates, Plant Physiol. 130 (2002) 15621572 . 


\section{Precursores de aromas glucosilados y glucosidasas en la "vaina" de Vanilla planifolia G. Jackson.}

Resumen - Introducción. Los tratamientos térmicos aplicados en las "vaina" de la vainilla (Vanilla planifolia G. Jackson) durante la transformación poseen objetivos diferentes, entre los cuales está el de favorecer la hidrólisis de los precursores glucosilados de compuestos de aroma mediante una (o varias) glucosidasa(s) endógena(s). Los glucósidos de la "vaina" de la vanilla. Alrededor de 15 glucósidos pudieron identificarse en el fruto verde, entre los cuales la glucovainilla es el más importante cuantitativamente. Su concentración puede alcanzar el 15\% de la materia seca del fruto, cerca de treinta semanas después de la polinización y este glucósido representa la principal forma de acumulación de la vainilla. $\beta$-D-glucosidasa(s) del "vaina" de la vainilla. Se purificó y se caracterizó una $\beta$-D-glucosidasa a partir del "vaina" de la vainilla, pero es posible que existan varias glucosidasas aún por estudiar. La actividad propia de la glucosidasa resulta muy inestable en el curso de los tratamientos térmicos, lo que plantea cuestiones relativas al proceso de hidrólisis de los glucósidos durante la transformación de la vainilla. Compartimentación entre actividad propia de la glucosidasa y glucósidos en el "vaina" de la vainilla. Tras diferentes controversias, parece aceptado que la glucovainilla y la actividad propia de la glucosidasa se localizan mayoritariamente en la parte placentaria de la "vaina". Su localización celular respectiva aún debe precisarse, sin embargo sendos elementos sostienen la hipótesis de que la hidrólisis enzimática se regula por una compartimentación celular diferente entre encima y sustrato. Conclusión. Siguen por emprenderse muchos trabajos de investigación relativos a los glucósidos y las glucosidasa(s) de la "vaina" de la vainilla; y, sería sobre todo interesante conocer mejor el desarrollo del proceso de hidrólisis enzimática de los precursores de aromas durante la transformación.

Vanilla planifolia / procesamiento / aroma / glucósidos / beta glucosidasa 